\title{
Four Wooden New Kingdom Female Statuettes in the Egyptian Museum, Cairo
}

\author{
AMr EL-TiEBI
}

\begin{abstract}
The author analyzes four wooden female statuettes from the collection of the Egyptian Museum in Cairo. All of them represent nude females and have many features in common. They were rendered in a way that emphasized their sexuality and fertility. Due to the lack of inscriptions their dating and function could be reconstructed only on the basis of analogies.
\end{abstract}

Keywords: New Kingdom Egypt, nude female, wooden statuettes, Egyptian Museum in Cairo, Eighteenth Dynasty

Amr El-Tiebi, Supreme Council of Antiquities, Cairo; amreltebie@yahoo.com

The Egyptian Museum in Cairo has an extensive collection of female statues dating from different periods of Egyptian history. Some of them still need comprehensive study to determine their provenance, dating and function. The aim of this article is to examine a group of these female wooden statuettes, which belong to the New Kingdom and have many features in common: they represent nude figures, standing with their legs closed together, looking straight ahead, wearing plain, short, round wigs reaching down to the neck, framing the face and covering the ears. Their breasts, abdominal muscles and thighs are sculpted in an exaggerated way and their nipples are modeled in relief. There are no inscriptions on the statuettes, so the identity of the figures remains unknown.

\section{STATUETTE NO. I, TR ${ }^{1}$ 18.2.23.7 (Fig. 1a-d)}

Its provenance is not known. The height of the statuette is $25 \mathrm{~cm}$. The wig has a longitudinal crack in the left side and there is some surface damage on the right arm. The feet are partially destroyed and the original base is lost. On the back of the statuette a deep crack extends from the left shoulder towards the neck down to the waist and there is another

\footnotetext{
${ }^{1}$ TR (i.e. Temporary Registration) is a numbering system in the Egyptian Museum, Cairo.
} 

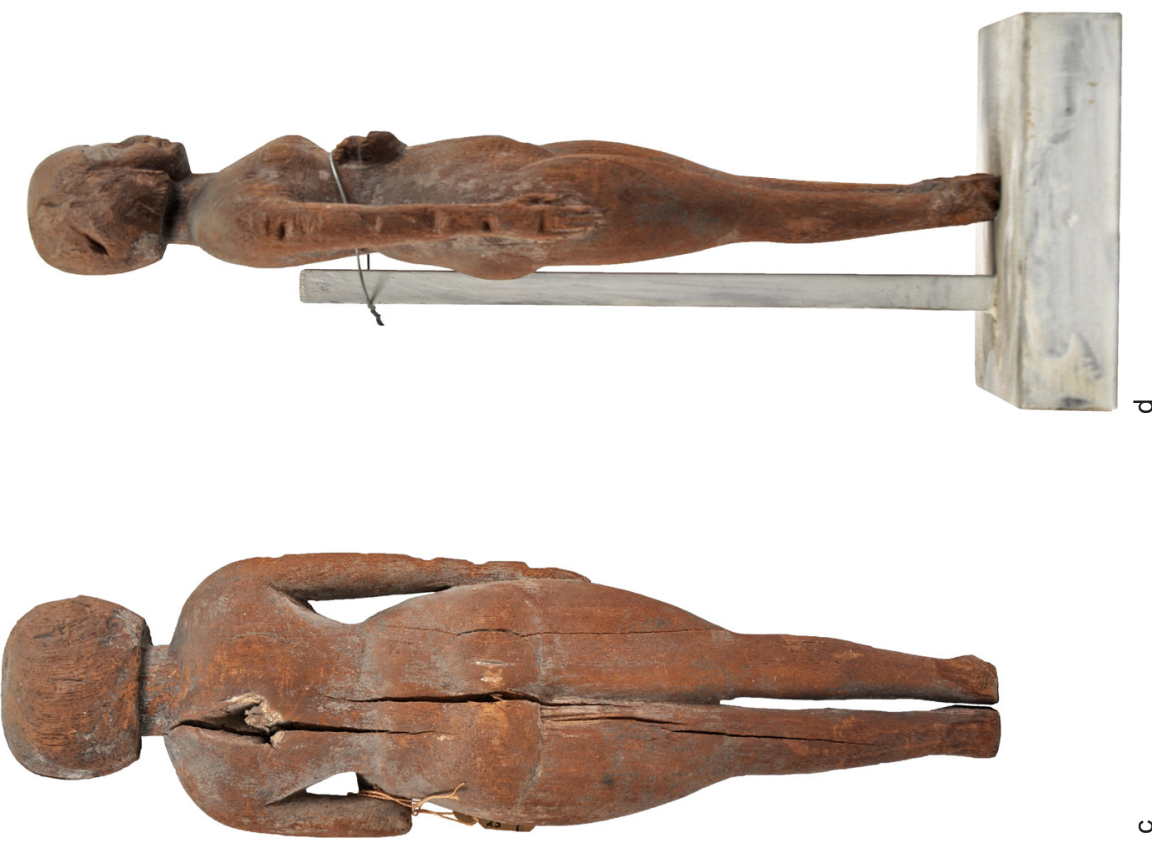

完

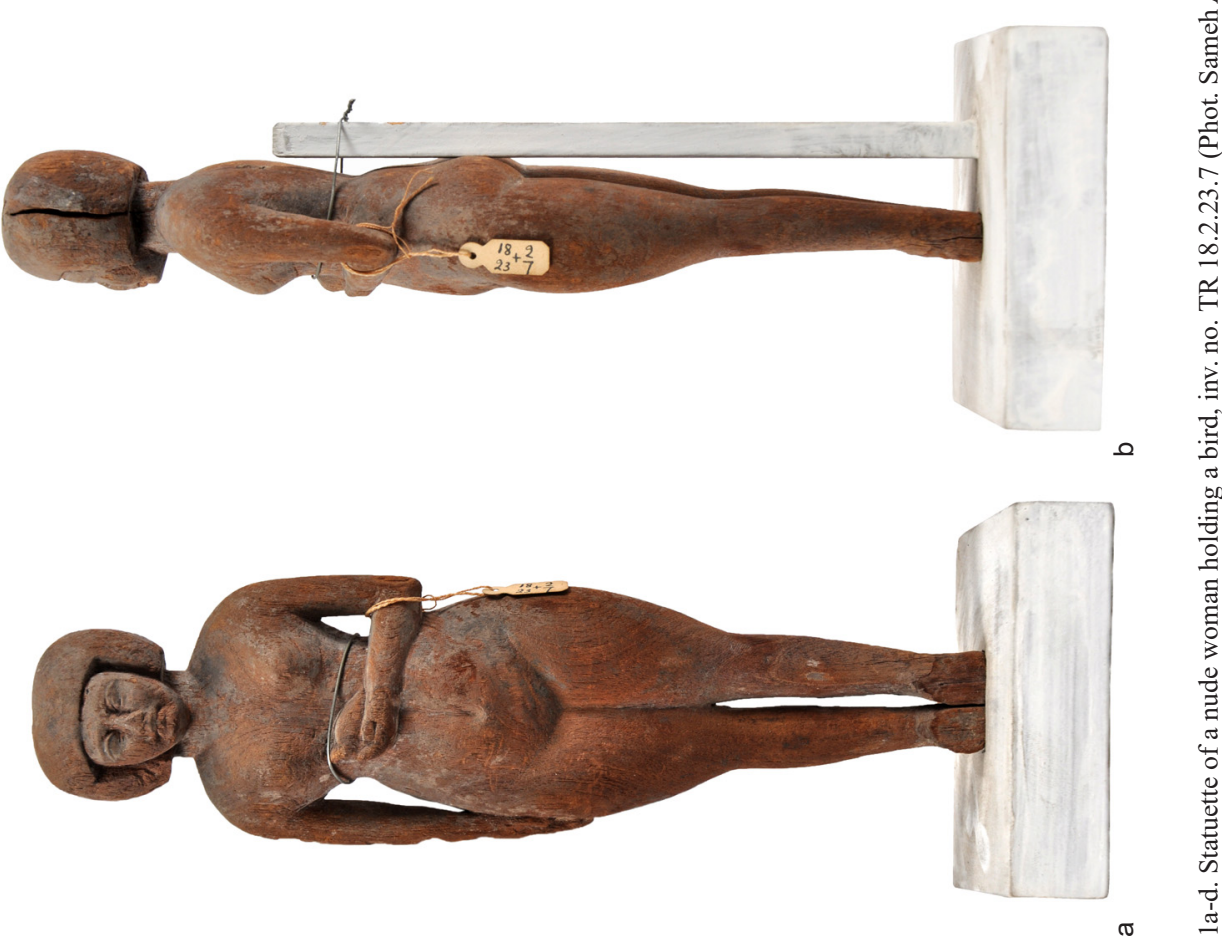

0 
longitudinal crack from her waist down to the buttocks. The tip of the nose is broken and the lips are partially eroded.

The female is represented with her right arm held at her side with the palm of the hand turned inward, while her left arm is bent at the elbow under her breasts and holding a bird in her hand. The species of the bird is difficult to determine. The arms are partially separated from the body. The woman has a heart-shaped face with broad cheeks narrowing towards a small chin, wide neck, large ovoid eyes, thin eyebrows and small mouth. In profile the belly protrudes visibly, the buttocks are not high, but sag somewhat.

Such a pose of carrying bird is first attested in the Eighteenth Dynasty, but it is documented also in later periods among representations of both elite and non-elite females. ${ }^{2}$ The depiction of the bird in such a context could be interpreted in several ways: it might be a symbol of a beloved man that the girl tries to ensnare in her net or trap, as confirmed by passages from love poetry; ${ }^{3}$ and it could also refer to the young bird as a symbol of the young man whose love has been captured by the beautiful maiden, a distinct reference to the sexual potential of the deceased in the afterlife. ${ }^{4}$

\section{ANALOGIES}

The nearest analogies occur among mirror $^{5}$ handles, such as:

1. A mirror handle in Museo Civico Archeologico, Bologne, inv. no. KS 1859 (Fig. 2), made of wood and inlaid with ivory. ${ }^{6}$ The height of the figure is $14.5 \mathrm{~cm}$. Its provenance is not known. ${ }^{7}$ However, E. Bresciani suggested that the figure may originate from the tomb of Horemheb at Thebes. ${ }^{8}$

The figurine depicts a nude ${ }^{9}$ girl standing with her left leg stepping forward and touching her tripartite wig with her right hand, while her left hand is against her chest, holding a small bird with raised wings. The girl wears an elaborate unguent-container on her head and ivory ear plugs. ${ }^{10}$

The object has been dated to the late Eighteenth Dynasty.

${ }^{2}$ Cf. Vandier 1941: 363-369; Aufrère 1996: 20-21; Derriks 2001: 68-69.

3 Peterson 1987: 25-26.

${ }^{4}$ Bailleul-LeSuer 2013: 157; Derchain 1975: 64.

${ }^{5}$ For the symbolism of mirrors, see: Kozloff 1984; Müller 1984.

${ }^{6}$ Vandier 1958: Pl. CXLI, Figs 6-7; Silverman 2002: 446, no. 146; Aldred 1951: 95, Pls 164-165; Arte 1994: 78; Maspero 1897: 533; 1912a: 237, Fig. 77; 1912b: 209, Fig. 392; 1913: 186; Capart 1903-1904: 35-36, Fig. 12; Bissing 1914: Pl. 50, Fig. 4; Fechheimer 1922: 31, Pl. 65; Curto 1961: 117, Pl. 56; 1984: 452; Pernigotti (Ed.) 1994: 78; Morigi Govi, Vitali, (Eds) 1982: 141; Boeser 1907: 181; Bresciani 1975: 51-52, Pls 25-26; Cesaretti 1990: no. 91; Kminek-Szedlo 1895: 162; Picchi (Ed.) 2016: 548, no. VI 54; Bellasi, Sparagni (Eds) 2006: 47, 73, 191, no. B65.

${ }^{7}$ Possibly it comes from Memphis (PM VIII' $\left.{ }^{2}, 695\right)$.

${ }^{8}$ Bresciani 1975: 51, Pls 25-26.

${ }^{9}$ For the symbolical significance of the image of the nude girl decorating mirror handles, see: Robins 1996: 32-33.

${ }^{10}$ Cf. Eaton-Krauss 1982: 227. 


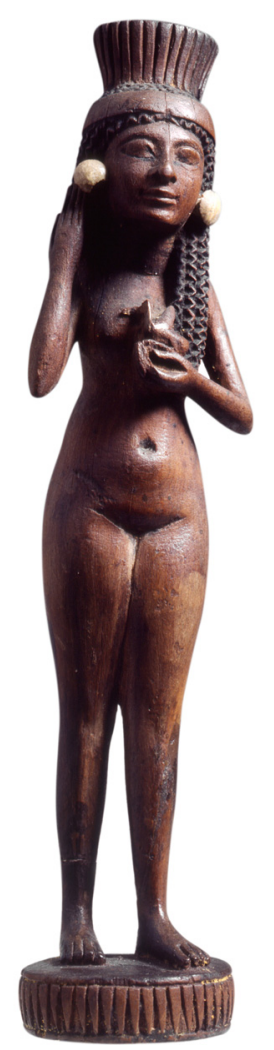

2. Mirror handle, inv. no. KS 1859 (C) Museo Civico Archeologico. Bologne).

2. A bronze mirror handle in the Brooklyn Museum, New York, Charles Edwin Wilbour Fund, acc. no. 60.27.1 (Fig. 3a). ${ }^{11}$ Its provenance is not known. The height of the figure, including the mirror, is $22.2 \mathrm{~cm}$. The disk is held in place by a rivet that passes through a stylized flattened headdress. The disk has a gilded reflective surface.

The handle has the shape of a female, with a typical Nubian appearance, standing on a rectangular base, with her left leg advanced, her right arm held at her side with the palm of the hand turned inward, while her left arm is bent at the elbow and is holding a bird. She is nude except for cross straps, a waist band, armlets and bracelets. These are indicated by incised lines, as are the creases at the neck, knees and belly, the pubic triangle with hair, stylized Bes tattoos on the thighs as well as tattoos and dimples above the buttocks. Tufts of hair protrude on the axial points of the head, these also being incised. The large pierced ears have the remains of one earring. ${ }^{12}$

C. Lilyquist pointed that the figure may be dated to the late Eighteenth Dynasty based on the type of the figure and the capital. ${ }^{13}$

\footnotetext{
${ }^{11}$ Fazzini 1975: no. 72; Cooney 1959-1960: 69; Eaton-Krauß 1976: no. 47.

12 Derriks 2001: 29, 176, Fig. 33, no. 63.

${ }^{13}$ Lilyquist 1982: 187-188.
} 
a
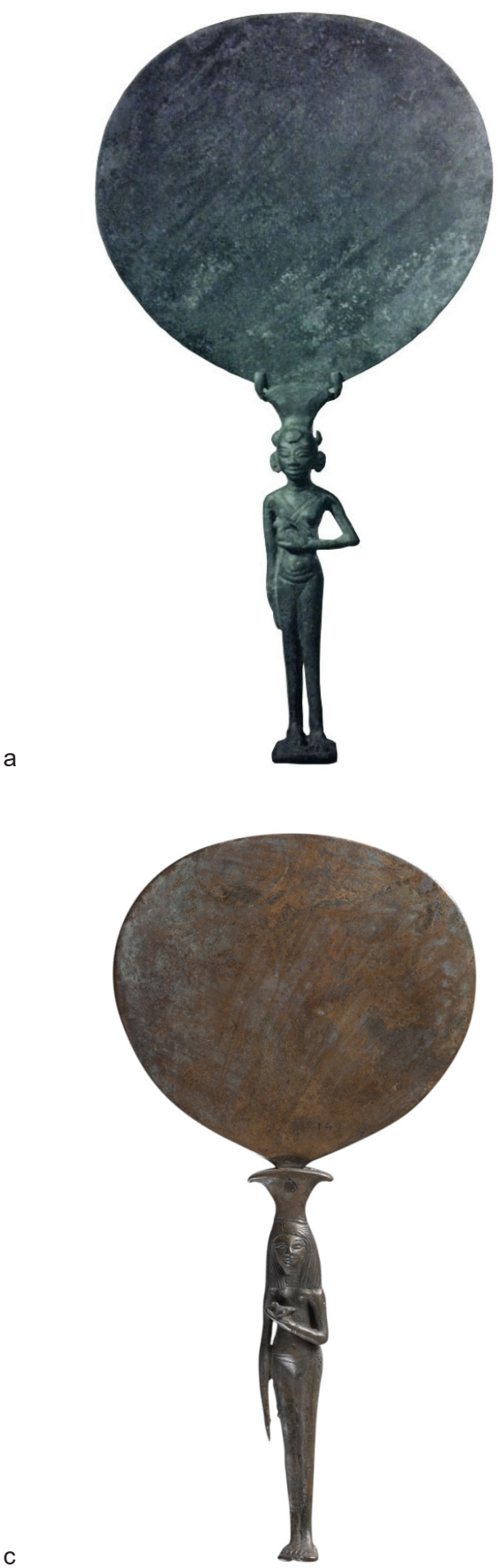

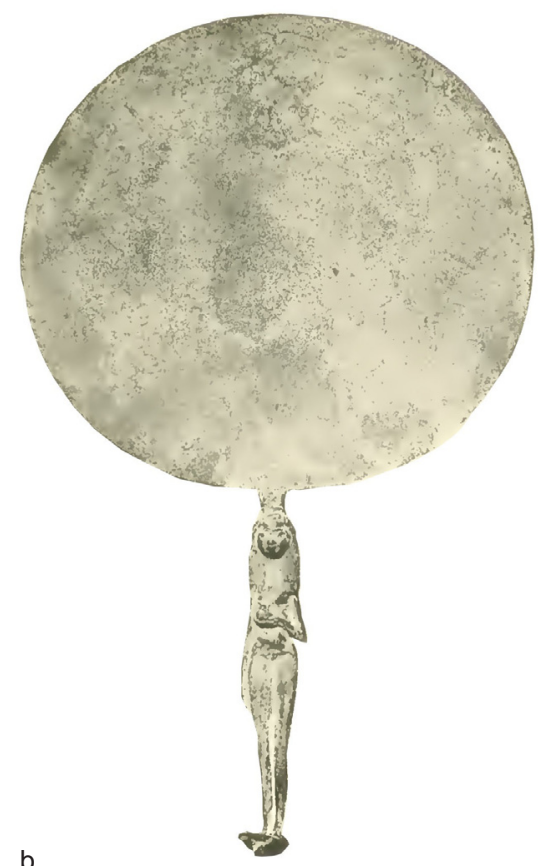

b

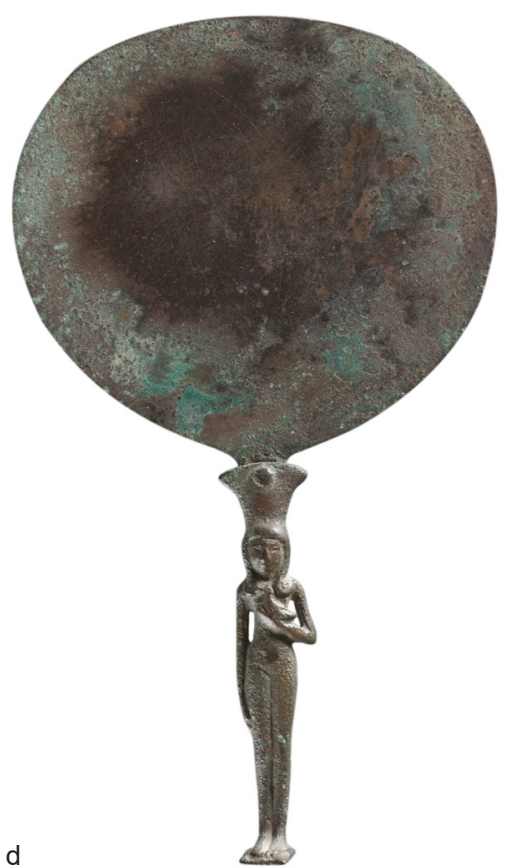

3. Mirror handles: a. inv. no. 60.27.1; b. CG 44038; c. N. 2149a; d. N. $2165=$ AF. 1677 (a. (C) Brooklyn Museum of Fine Art, New York; b. Phot. Sameh Abd el Mohsen (C) Egyptian Museum, Cairo; c-d. Phot. Ch. Décamps, Musée du Louvre). 
3. A mirror handle in the Egyptian Museum, Cairo, inv. no. CG 44038 (Fig. 3b), ${ }^{14}$ found in Akhmim. The height of the figure is $21.5 \mathrm{~cm}$. The disk of the mirror was made of a bronze leaf and the handle - which is now missing ${ }^{15}$ - was melted. The two parts were joined by welding and the stem was consolidated by a copper tape. The mirror has a thin, almost regularly rounded, disk.

The handle is in the form of a female represented nude, standing on a small triangular base with her left leg advanced. Her right arm is held at her side, while her left arm is folded at the elbow against her breasts and holding a bird(?). She wears an enveloping wig that M.G. Bénédite considered to be of Theban type. The face is eroded, so her facial features remain unclear.

The mirror has been dated to the New Kingdom. ${ }^{16}$

4. A bronze mirror handle in the Louvre Museum, Paris, inv. no. N. 2149a (Fig. 3c) ${ }^{17}$ It comes from the Clot bey collection. Its provenance is not known. The height of the figure is $24.5 \mathrm{~cm}$. The mirror has nearly round disk.

The handle is in the form of a nude female standing with her right arm hanging down by her side reaching to her knee, while her left arm is bent against her breasts and holding a bird in her hand. She has long, slender legs. The female wears an enveloping wig, collar, bracelet and waist band.

J. Vandier dated the mirror to the late New Kingdom. ${ }^{18}$

5. A bronze mirror handle in the Louvre Museum, Paris, inv. no. N. $2165=$ AF. 1677 (Fig. 3d). ${ }^{19}$ Its provenance is not known. The height of the figure is $21 \mathrm{~cm}$. The mirror has a slightly oval disk.

The handle is in the form of a nude female standing with her right arm hanging down by her body, while her left arm is bent against her breasts and holds a bird in her left hand; two locks of hair reminiscent of the curls of the Hathor wig fall on her breasts and a third falls on her back. She wears a little modius in the form of a bunch of papyrus flowers on her head, aimed to secure the post of the disc.

J. Vandier dated the mirror to the late New Kingdom. ${ }^{20}$

6. A bronze mirror handle in the Museum of Fine Arts, Boston, inv. no. 41.263. ${ }^{21}$ Its provenance is not known. The height of the figure is $28 \mathrm{~cm}$. The mirror has a slightly oval disk connected to the handle by a lily flower. The figure forming the handle is cast separately from the mirror itself.

\footnotetext{
14 Bénédite 1907: 20, Pl. X.

15 The present author investigated the figure and found that the disk is only preserved, while the handle is now missing.

16 Bénédite 1907: XXXIV; Derriks 2001: 33, Fig. 39, no. 83.

17 Boreux 1932: 629; Vandier 1972: 167, no. 748; Derriks 2001: 29, 179, no. 66.

18 Vandier 1972: 167, no. 748.

19 Vandier 1972: 167, no. 749; Champollion 1827: 74, nos 4-5.

20 Vandier 1972: 167, no. 749; Derriks 2001: 29, 180, no. 67.

${ }^{21}$ Smith 1960: 120-121; Terrace 1968: 49-56.
} 
The handle is in the form of a nude girl, with a typical Nubian appearance, standing with her left leg advanced, her right arm held at her side with the hand clenched to hold an object now lost, while her left arm is bent at the elbow under her breasts and holding a bird. She wears a short, round, elaborate wig reaching down to the neck, framing the face and covering the ears.

The figure has been dated to the Eighteenth Dynasty. ${ }^{22}$

\section{STATUETTE NO. II, CG 775 (Fig. 4a-d)}

The provenance of this statuette ${ }^{23}$ is not known. It has the same height as statuette no. I. The nose is broken. The back of the wig and the left side of the buttock have cracks. The right arm and front part of the footplate are missing.

The female is represented standing with her left arm hanging down by her side and the hand opened, palm turned outward. The left arm is attached to the body with a wooden peg in an irregular way. It is definitely too short for this otherwise well-proportioned body. It seems possible therefore that the arm originally did not belong to this figure, but was mounted later. The facial features are characterized by incised eyebrows, large eyes, broad cheeks, full lips mouth and small chin. The figure has small feet with traces of red-brown color. The woman has very narrow shoulders, high waist, wide hips and a prominent pubic mound. The expense of the round belly, buttocks and thighs are reminiscent of the representations in relief and statuary of Amarna art, where the figures of Akhenaten and his family are represented with wide hips, round bellies, high waists, large breasts, narrow shoulders, and slender limbs. ${ }^{24}$

\section{ANALOGIES}

The female's wig is reminiscent of the wig depicted on wooden head of queen Tiy, the chief wife of Amenhotep III, mother of Akhenaten, which comes from Medinet el-Ghurob, Faiyum, and is now in the Ägyptisches Museum, Berlin, inv. no. 21834 (Fig. 5a). The small head in its original version - without the double feathers crown - portrayed the queen wearing a short, round wig covered with tiny blue glass beads, hiding a silver khat-headdress, which can still be glimpsed above the forehead, at the neck and through a hole on the head. ${ }^{25}$

22 Simpson 1977: 41, 68, Fig. 35; Wenig 1969: 52, Pl. 84; Derriks 2001: 31, 195, Fig. 37, no. 78.

23 Borchardt 1930: 86; Vandier 1958: 657; PM VIII², 696.

24 Robins 1993: 29.

25 Borchardt 1911: Pls 1-4; Schäfer 1923: ii; 1931: Pl. 10; 1932: 81-86; Steindorff 1926: 47, Fig. 42; Kees 1933: P1. 48; PM IV, 113; Kaiser 1967: 61, no. 676; Michalowski 1969: 389, 451, P1. 383; Wenig 1969: 50, no. 59; Müller 1970: Pl. XXXVI, no. 117; Aldred 1973: 105, no. 19; Settgast 1976: no. 74; Bryan, Kozloff, Berman 1992: 209-210; Fay 1992: 72, no. 37; Hamann 1944: 237-238; Arnold 1997: 30; Wildung 1998: 22; 1999: 215, no. 39; Hawass 1998: 39-40; Malek 2003: 168; Tiradritti 2007: 72; Kessler 2009: 146; Seyfried 2012: 202, no. 4. 

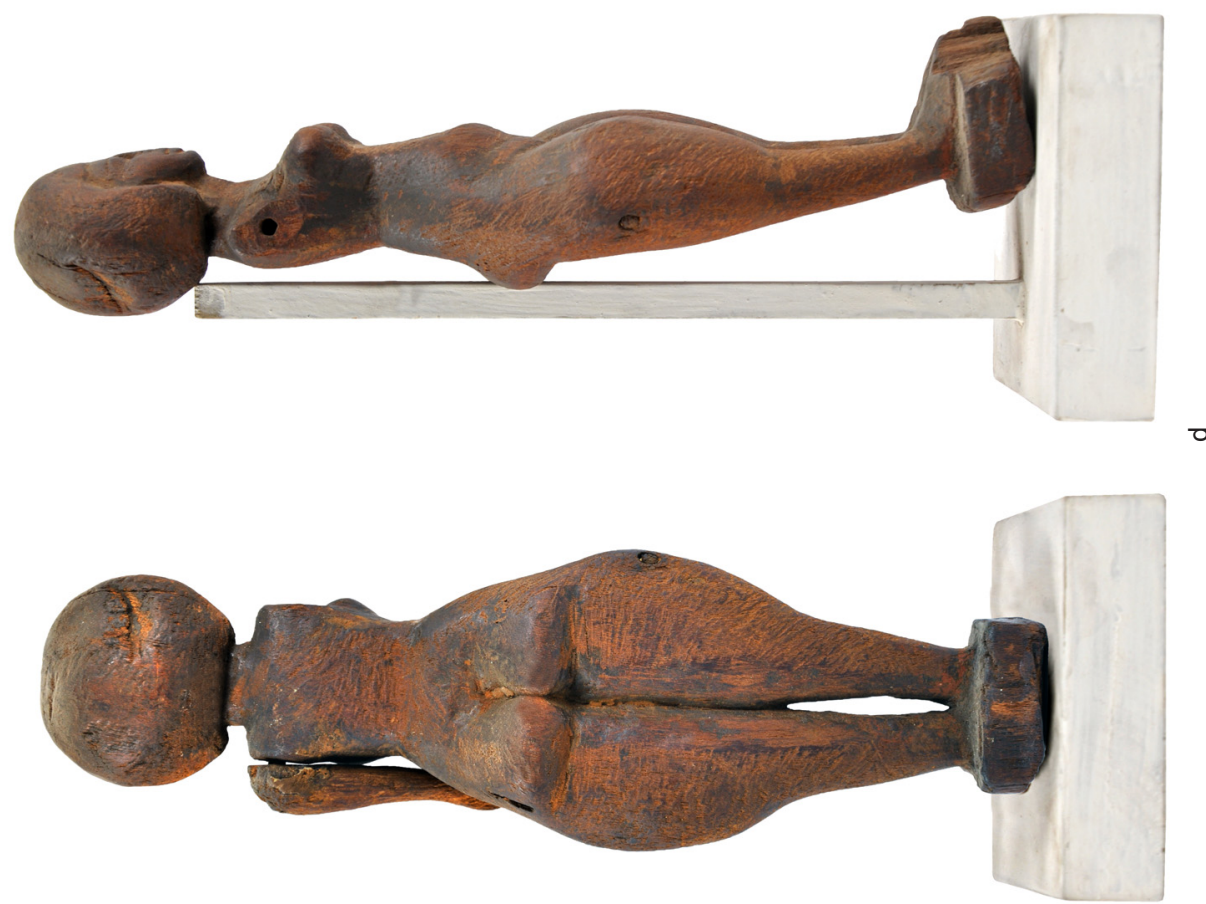

0 官
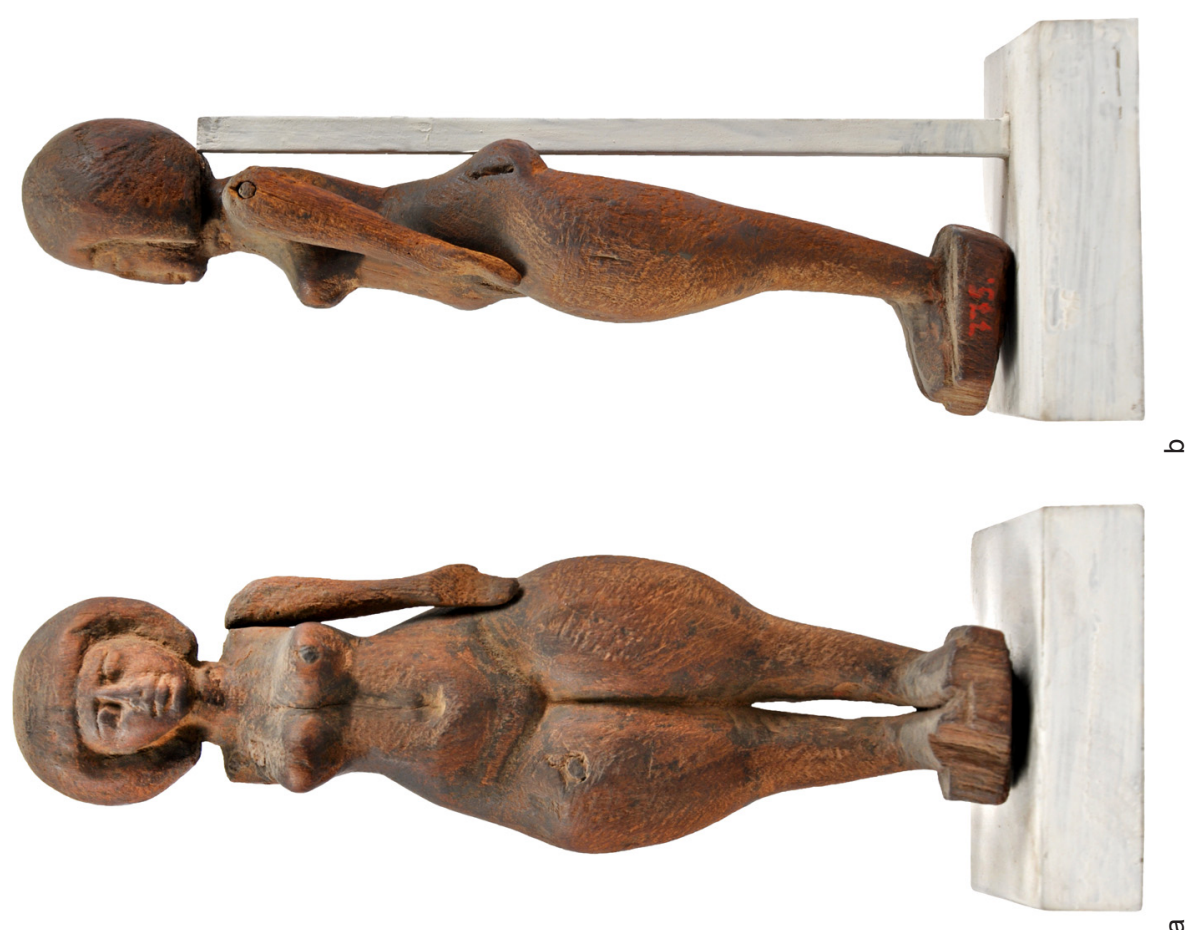

尝

in 


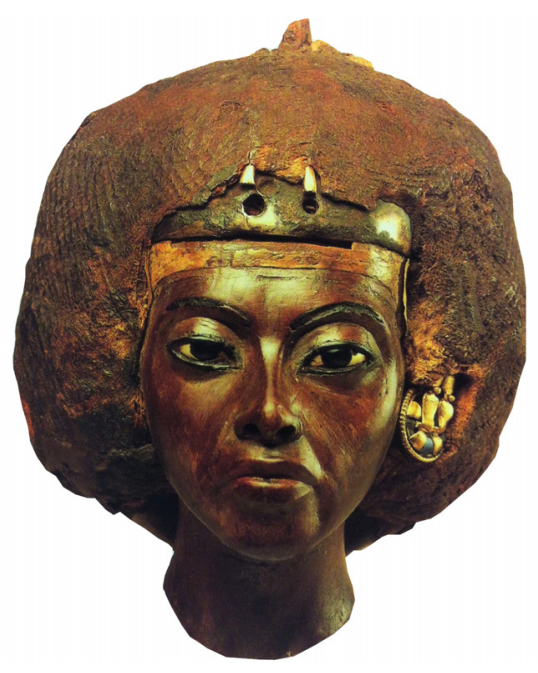

5a. Head of Queen Tiy, inv. no. 21834; b. nude woman statuette, inv. no. UC 8829 (a. C Egyptian Museum, Berlin; b. (C) Petrie Museum, University College, London).

Another statuette that has been compared with our statuette no. II is in the Petrie Museum, University College, London, inv. no. UC 8829, of unknown provenance (Fig. 5b). ${ }^{26}$ The statuette is dated to the New Kingdom. It is made of wood, and measures $22.7 \mathrm{~cm}$ height. The left arm has been broken off and the front of the left foot, as well as the base, are lost. There is a large crack down the top of the right shoulder.

The statuette represents a standing nude female with her feet together on a small base. She wears a short wig, which curves above her brow and behind the ears, and is cut straight at the back of the head. She has a round face, but the facial features are strongly effaced, and the ears appear only as indentation in the wig. The figure has narrow sloping shoulders, a small high waist, large rounded breasts and wide hips. Her right arm hangs at her side with the hand open against her thigh. The left arm is bent across her breasts with the hand clenched. In the opinion of the present author, the statuette should rather be compared to our statuette no. I, notwithstanding the bird.

\footnotetext{
26 Page 1976: 77, no. 82 .
} 

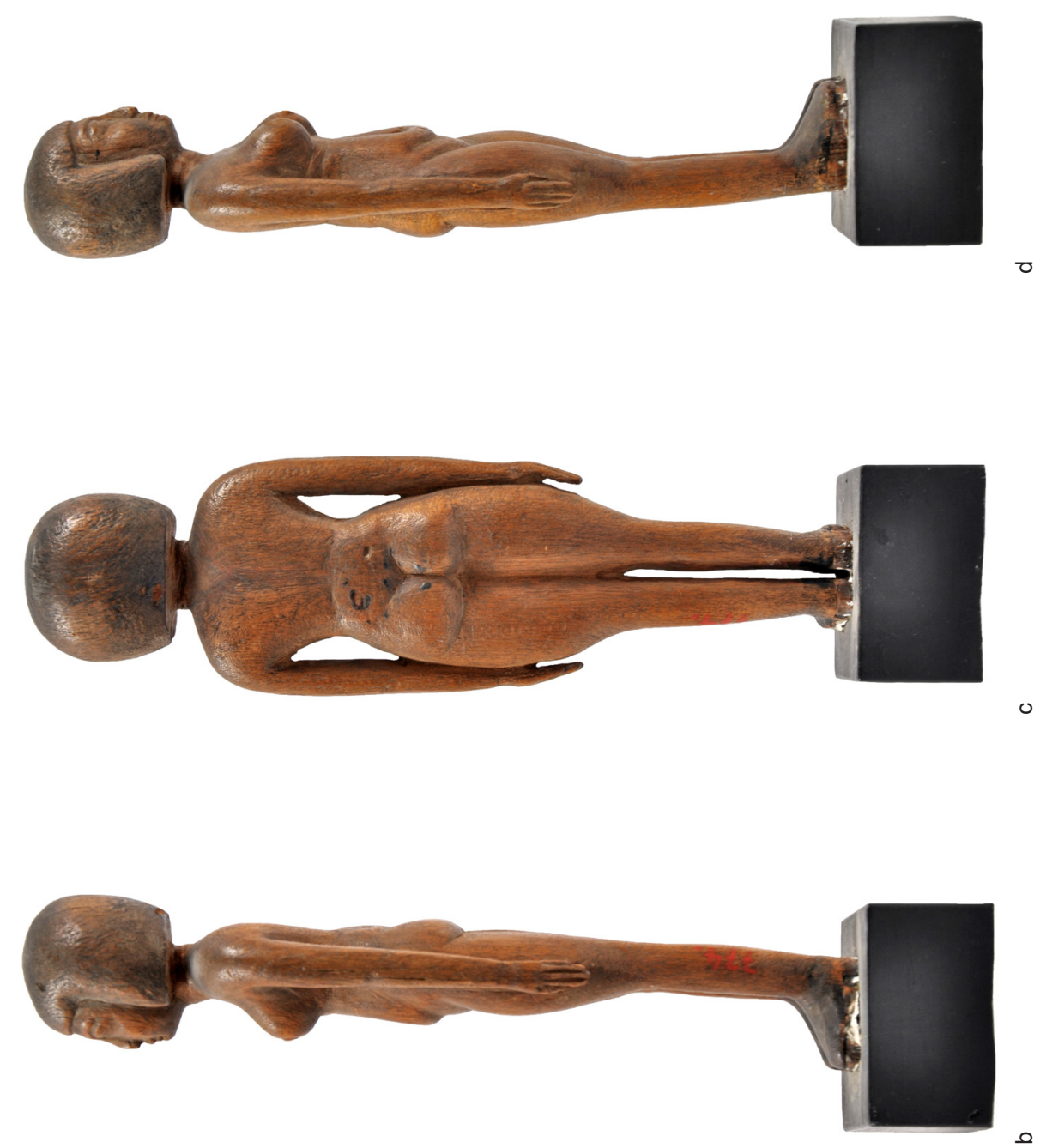

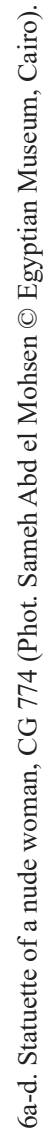




\section{STATUETTE NO. III, CG 774 (Fig. 6a-d)}

The third wooden statuette ${ }^{27}$ was found - according to L. Borchardt - in an Eighteenth Dynasty tomb at Deir el-Bahari. ${ }^{28}$ It measures $20 \mathrm{~cm}$ in height and is almost completely preserved, while only the tip of nose is broken.

Despite its small size, the statuette is definetely one of the most beautiful sculptures of this group. The female is represented with arms held down by her sides, the palm of the hands turned inward and her legs are attached to the base. She wears nothing except for a simple painted necklace adorning her neck, the traces of which are still preserved on the chest. Her facial features are precisely modeled: she has a full face with large ovoid eyes, incised eyebrows, convex cheeks, small mouth with the upper full and pointed lip, while the lower one being less prominent, and a tiny chin. The arms and legs of the woman are partly separated from the body and the toes are not specified. The pubic area is indicated by dots. There are traces of black color on the wig. The emphasis on the sexual characteristics and the fullness of the hips might have meant that such a figure appeared as a fertility symbol. ${ }^{29}$

\section{AnAlogies}

This representation can be compared with the wooden female statuette displayed in the National Museum of Antiquities in Leiden, inv. no. AH 196. The statuette is dated to the New Kingdom and measures $33.5 \mathrm{~cm}$ in height. Its provenance is not known. The figure depicts a standing unclad female with her feet together on a small base. She is represented with arms held by her sides, the palm of the hands turned inward. Her left arm is adorned with a bangle. ${ }^{30}$

\section{STATUETTE NO. IV, CG 776 (Fig. 7a-d)}

This statuette ${ }^{31}$ of unknown provenance measures $20.5 \mathrm{~cm}$ in height. The arms are missing and the round face is partially eroded, so the facial features remain unclear and the footplate is partially damaged.

The statuette represents a standing nude female. She has narrow shoulders, a high waist, a prominent pubic mound, long, slender legs and small feet; the toes are not specified.

\footnotetext{
27 Vandier 1958: 657; Borchardt 1930: 85.

28 Borchardt 1930: 85.

${ }^{29}$ Wildung, Schoske (Eds) 1984: 138, no. 64.

${ }^{30}$ Fasson 2016: 550, cat. no. VI.63; Boeser 1907: 155; 1925: 8, no. 41; PM VIII², 698.

31 Borchardt 1930: 86; Vandier 1958: 657; PM VIII², 696.
} 
Amr EL-Tiebi

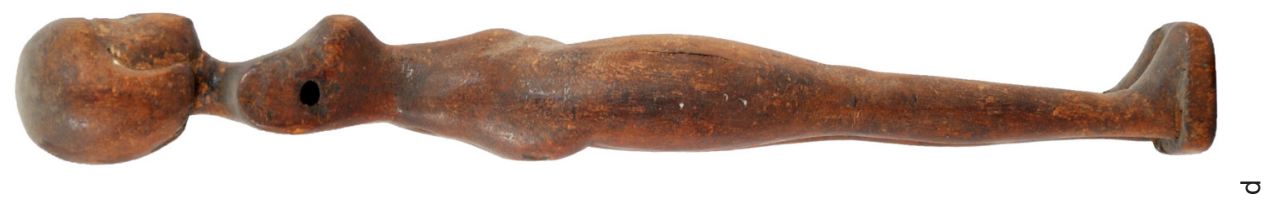

0

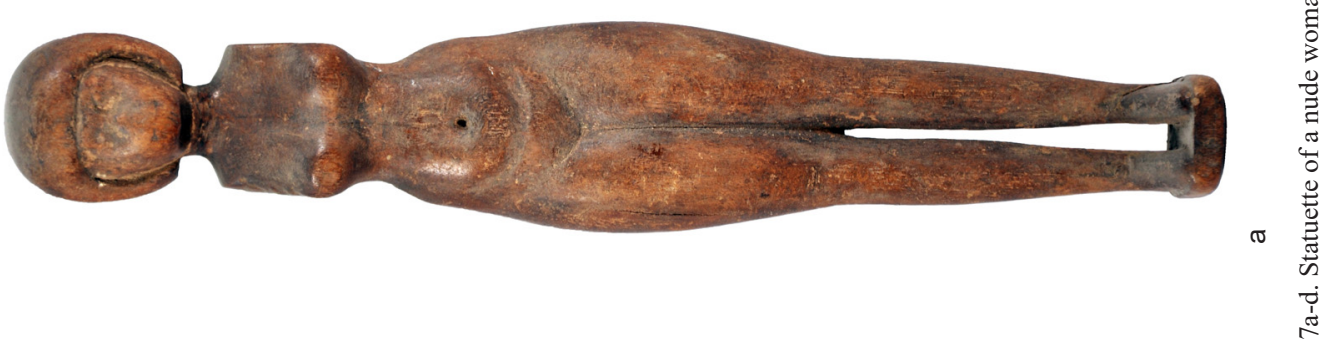




\section{Analogies}

The wig of this statuette strongly resembles the wig of a wooden head of a female kept in the Petrie Museum, University College, London, inv. no. UC 8830. The height of the head is $6.2 \mathrm{~cm}$. The provenance is not known. It is dated to the New Kingdom. ${ }^{32}$

\section{COMMENTARY}

Two iconographic features of the four figures deserve particular attention with respect to their dating and function.

The first is their nudity. In their art and literature, the Egyptians used nudity to convey more than social status. The nude or partially nude human figure could express several emotions and serve cultic functions. It is not surprising that the depictions of unclothed females should be overwhelmingly connected with sex and fertility. During the second half of the Eighteenth Dynasty nude or dressed women were usually rendered in a way that emphasized their sexuality and fertility: a pretty, youthful face, full breasts set off by a small waist and wide hips, callipygian buttocks, the pubic triangle usually distinct, even prominent. Unless they are shown working or embracing a family member, freestanding representations of women in the round, whether these females are dressed or not, usually appear with arms held tightly at their sides,${ }^{33}$ holding a pet, fruit, sistrum, flower or a bird in one hand.

The second detail of particular interest is the wig. The representations of women wearing short, round wigs reaching down to the neck, framing the face and covering the ears, are attested in the iconography of both elite and non-elite women in the Old and Middle Kingdoms, and again in the Late period. However, during the New Kingdom, this type seems to be confined to servants, although its significance is unclear, as observed by G. Robins. ${ }^{34}$

Considering the nudity of the figures, the type of the wig worn, the tender, smooth surface treatment, especially the facial features, and the carving style, we can conclude that the statuettes under study belonged most probably to the late Eighteenth Dynasty, represented servants and their forms have been accentuated to show their sex-appeal or fertility.

These female figures have been found in different contexts and most likely served various purposes. In the world of the living, some figures may have been magical guarantors of fertility to both mothers and children who had reached the age of puberty. As burial equipment, the figures probably represented the potential for rebirth and procreation, thus assuring continuity and immortality in the afterlife for both genders.

\footnotetext{
32 Page 1976: 78, no. 83 .

33 Goelet 1993: 20, 25, 26; Behrens 1982: 291-294; Robins 1996: 30, 39.

34 Robins 1999: 64.
} 


\section{Acknowledgments}

I owe a great debt of gratitude to Prof. Dr. Karol Myśliwiec for his comments on the first draft of this article as well as his constant support of my research.

\section{References}

Aldred, C. 1951: New Kingdom Art in Ancient Egypt during the Eighteenth Dynasty 1590 to 1315 B.C., London

Aldred, C. 1973: Akhenaten and Nefertiti, New York

Arnold, Do. 1996: An Artistic Revolution: The Early Years of King Amenhotep IV / Akhenaten, [in:] Arnold, Do., Green, L., Allen, J.P., The Royal Women of Amarna: Images of Beauty from Ancient Egypt, New York, 17-39

Arte, L. 1994: La Collezione Egiziana, Museo Civico Archeologico di Bologna, Rome Aufrère, S.H. 1996: Les collections égyptiennes de Toulouse conservées au Musée Georges-Labit, Les Cahiers du Musée Georges-Labit 1, Toulouse

Bailleul-LeSuer, R. 2013: Bird Motifs in Ancient Egyptian Arts and Crafts, [in:] Bailleul-LeSuer, R. (Ed.), Between Heaven and Earth: Birds in Ancient Egypt, Oriental Institute Museum Publications 35, Chicago, 157-166

Behrens, P. 1982: Nacktheit, [in:] L̈̈ 4, 291-294

Bellasi, P., Sparagni, T. (Eds) 2006: Un diavolo per capello: Dalla sfinge a Warhol Arte Acconciature Società, Milano

Bénédite, M.G. 1907: Miroirs, Catalogue Géneral des Antiquités Égyptiennes du Musée du Caire, Nos 44001-44102, Le Caire

Bissing, F.W. Freiherr von 1914: Denkmäler ägyptischer Sculptur, München

Boeser, P.A.A. 1907: Catalogus van het Rijksmuseum van Oudheden te Leiden: Egyptische afdeeling, Leiden

Boeser, P.A.A. 1925: Beschrijving van de Egyptische Verzameling XII, Den Haag

Borchardt, L. 1911: Ausgrabungen der Deutschen Orient-Gesellschaft in Tell el-Amarna I:

Der Porträtkopf der Königin Teje im Besitz von Dr. James Simon in Berlin, WVDOG 18, Leipzig

Borchardt 1930: Statuen und Statuetten von Königen und Privatleuten III, Catalogue Géneral des Antiquités Égyptiennes du Musée du Caire, N ${ }^{\text {os }}$ 654-950, Berlin

Boreux, Ch. 1932: Musée National du Louvre: Département des antiquités égyptiennes, Guide-catalogue sommaire II: Salles du I ${ }^{\text {er }}$ étage (Salles Charles X), Paris

Bresciani, E. 1975: La collezione egizia nel Museo Civico di Bologna, Ravenna Capart, J. 1903-1904: Les débuts de l'art en Égypte, Bruxelles

Cesaretti, M.P. 1990: Pannello a rilievo di Ptahemuia, [in:] Il senso dell'arte nell'antico Egitto, Bologna, Museo Civico Archeologico, 25 marzo -15 luglio, Milan

Champollion, J.-F. 1827: Notice descriptive des monuments égyptiens du musée Charles X, Paris

Cooney, J.D. 1959-1960: Curatorial Departments: Department of Ancient Art, The Brooklyn Museum Annals I, 41-43 
Curto, S. 1961: L'Egitto antico nelle collezioni dell'Italia settentrionale, Museo Civico, 31 Ottobre - 3 Dicembre 1961, Bologna

Curto, S. 1984: L'antico Egitto nel Museo Egizio di Torino, Torino

Derchain, P. 1975: La perruque et le cristal, $S A K$ 2, 55-74

Derriks, C. 2001: Les miroirs cariatides égyptiens en bronze: typologie, chronologie et symbolique, $M \ddot{A} S$ 51, Mainz a/Rhein

Eaton-Krauß, M. 1976: Spiegel mit figürlichem Griff, [in:] Karig, J.S., Zauzich, K.-T. (Eds), Ägyptische Kunst aus dem Brooklyn Museum, 4. September - 31. Oktober, Berlin, no. 47

Eaton-Krauss, M. 1982: Earrings, [in:] Freed, R.E. (Ed.), Egypt's Golden Age: The Art of Living in the New Kingdom 1558-1085 BC., Catalogue of the Exhibition, Museum of Fine Arts Boston, February 3 - May 2 1982, Boston, 227

Fasson, A. 2016: Female statuette, [in:] Giovetti, P., Picchi, D. (Eds), Egypt: Millenary Splendour. The Leiden Collection in Bologna, Milan, 550

Fay, B. 1992: Egyptian Museum Berlin, Berlin

Fazzini, R. 1975: Images for Eternity: Egyptian Art from Berkeley and Brooklyn, San Francisco-Brooklyn

Fechheimer, H. 1922: Kleinplastik der Ägypter, Berlin

Goelet, O. 1993: Nudity in Ancient Egypt, Source. Notes in the History of Art 12/2, 20-31

Hamann, R. 1944: Ägyptische Kunst: Wesen und Geschichte, Berlin

Hawass, Z. 1998: Silent Images: Women in Pharaonic Egypt, Cairo

Kaiser, W. 1967: Ägyptisches Museum, Berlin

Kees, H. 1933: Kulturgeschichte des Alten Orients I: Ägypten, $H A W 3 / 1 / 3$, München

Kessler, D. 2009: The Political History of the Eighteenth to Twentieth Dynasties, [in:]

Schulz, R., Seidel, M. (Eds), Egypt: The World of the Pharaohs, Cairo, 142-151

Kminek-Szedlo, G. 1895: Museo Civico di Bologna: Catalogo di Antichità Egizie, Torino

Kozloff, A.P. 1984: Mirror, Mirror, BCMA 71/8, 271-276

Kozloff, A.P., Bryan, B.M., Berman, L.M. 1992: Egypt's Dazzling Sun: Amenhotep III and His World, Cleveland

Lilyquist, C. 1982: Mirror with Nubian figure, [in:] Egypt's Golden Age: The Art of Living in the New Kingdom 1558-1085 BC., Catalogue of the Exhibition, Museum of Fine Arts Boston, February 3 - May 2 1982, Boston, 187-188

Malek, J. 2003: Egypt: 4000 Years of Art, London-New York

Maspero, G. 1897: Histoire ancienne des peuples de l'Orient classique II: Les premières mélées des peuples, Paris

Maspero, G. 1912a: Essais sur l'art égyptien, Paris

Maspero, G. 1912b: Histoire générale de l'art: Égypte, Paris

Maspero, G. 1913: Egyptian Art, London

Michalowski, K. 1969: Art of Ancient Egypt, New York

Morigi Govi, C., Vitali, D. (Eds) 1982: Il Museo Civico Archeologico di Bologna, Bologna

Müller, C. 1984: Spiegel, [in:] L̈̈ V, 1147-1150

Müller, H.W. 1970: Ägyptische Kunst, Frankfurt a/Main 
Page, A. 1976: Egyptian Sculpture: Archaic to Saite, from the Petrie Collection, Warminster Pernigotti, S. (Ed.) 1994: La collezione egiziana, Museo Civico Archeologico di Bologna, Bologna

Peterson, B. 1987: Egyptian Symbols of Love, MedMus-Bull 22, 23-27

Picchi, D. (Ed.) 2016: Mirror handle in the shape of a girl with earrings, [in:] Giovetti, P., Picchi, D. (Eds), Egypt: Millenary Splendour. The Leiden Collection in Bologna, Milan, 548

Robins, G. 1993: The representation of sexual characteristics in Amarna art, JSSEA XXIII, 29-41

Robins, G. 1996: Dress, undress, and the representation of fertility and potency in New Kingdom Egyptian art, [in:] Kampen, N.B. (Ed.), Sexuality in ancient art: Near East, Egypt, Greece, and Italy, Cambridge-New York, 27-40

Robins, G. 1999: Hair and the Construction of Identity in Ancient Egypt, c. 1480-1350 B.C., JARCE XXXVI, 55-69

Schäfer, H. 1923: Kunstwerke aus El-Amarna: Meisterwerke in Berlin, Berlin

Schäfer, H. 1931: Amarna in Religion und Kunst, Deutschen Orient-Gesellschaft, Sendschriften 7, Leipzig

Schäfer, H. 1932: Das Simonsche Holzköpfchen der Königin Teje, ZÄS 68, 81-86

Settgast, J. 1976: Königin Teye, [in:] Nofretete - Echnaton - Tutanchamun, Mainz a/Rhein

Seyfried, F. 2012: In the Light of Amarna: 100 Years of the Nefertiti Discovery, Berlin

Silverman, D.P. 2002: Mirror Handle, [in:] Ziegler, C. (Ed.), The Pharaohs, Milan, 446

Simpson, W.K. 1977: The Face of Egypt: Permanence and Change in Egyptian Art, New York

Smith, W.S. 1960: Ancient Egypt as Represented in the Museum of Fine Arts, Boston

Steindorff, G. 1926: Die Blütezeit des Pharaonenreichs, Monographien zur Weltgeschichte 10, Bielefeld-Leipzig

Terrace, E.L.B. 1968: The Age of Empire and Rebellion: The New Kingdom in Boston, Connoisseur 169/679, 49-56

Tiradritti, F. 2007: Ancient Egypt: Art, architecture and history, Milan

Vandier, J. 1941: La statue N. 608 du Musée Saint-Raymond de Toulouse, [in:] Miscellanea Gregoriana: raccolta di scritti, pubblicati nel I centenario, dalla fondazione del Pont. Museo egizio (1839-1939), Monumenti Musei e Gallerie Pontificie, Monumenti Vaticani di Archeologia e d'Arte 6, Vatican, 363-369

Vandier, J. 1958: Manuel d'archéologie égyptienne III: Les grandes époques. La statuaire, Paris Vandier, J. 1972: Catalogue des objets de toilette égyptiens, Paris

Wenig, S. 1969: The Woman in Egyptian Art, Leipzig

Wildung, D. 1998: Egyptian Art in Berlin: Masterpieces in the Bodemuseum and in Charlottenburg, Berlin

Wildung, D. 1999: Queen Tiye wearing a Hathor headdress, [in:] Freed, R.E., Markowitz, Y.J., D'Auria, S.H. (Eds), Pharaohs of the Sun: Akhenaten - Nefertiti - Tutankhamen, Boston, 215

Wildung, D., Schoske, S. (Eds) 1984: Nofret - Die Schöne: Die Frau im Alten Ägypten, Mainz a/Rhein 


\section{ÉTUDES et TRAVAUX XXX / 2017}

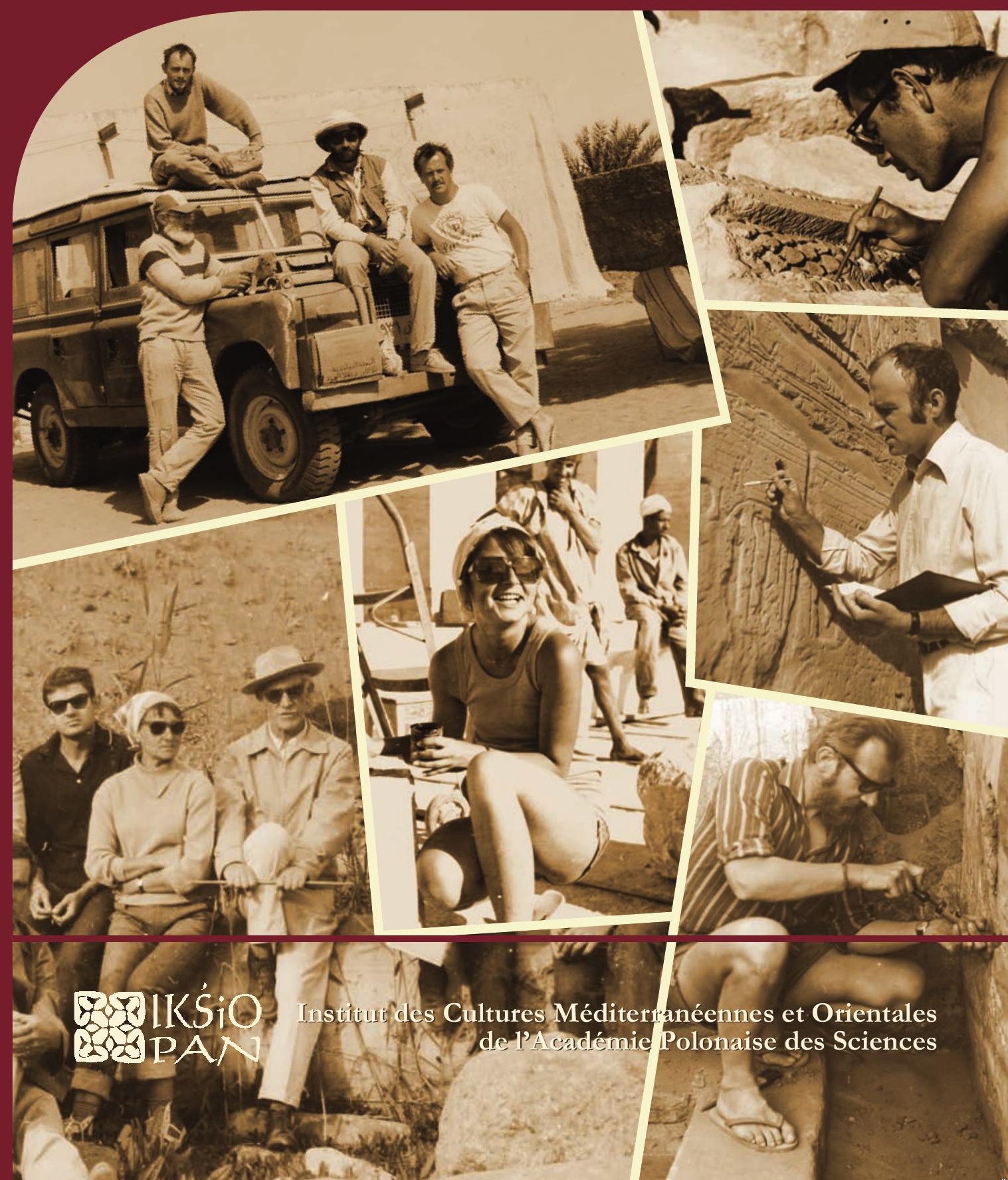




\title{
COMITÉ DE RÉDACTION SCIENTIFIQUE
}

Maciej Makowski - rédacteur en chef

Jadwiga Iwaszczuk - rédacteur et sécretaire de la rédaction

Mariusz Drzewiecki - rédacteur

Maciej G. Witkowski - rédacteur

\section{CONSEIL SCIENTIFIQUE DU JOURNAL}

M. Kobusiewicz (IAE PAS, Warszawa), E. Laskowska-Kusztal (IMOC PAS, Warszawa),

D. Michaelides (University of Cyprus, Nicosia),

J.Ch. Moretti (IRAA-MOM, Université de Lyon 2/CNRS),

D. Raue (Ägyptisches Museum der Universität Leipzig), P. Reynolds (ICREA, Barcelona),

D. Welsby (British Museum, London)

\section{COMITÉ SCIENTIFIQUE DE LECTURE}

J. Holaubek (Institut für Ägyptologie, Wien), S. Ikram (AUC, Cairo),

K. Innemée (Universiteit Leiden), J. McKenzie (Faculty of Oriental Studies, University of Oxford),

N. Strudwick (University of Cambridge), A. Loprieno-Gnirs (Universität Basel),

Ch.E. Loeben (Museen für Kulturgeschichte, Hannover), Y. Tristant (Macquarie University, Sydney),

V.W.J. van Gerven Oei (University of Aberdeen), A. Peignard-Giros (HiSoMA-MOM, Université de Lyon 2/CNRS), J.A. Ostrowski, E. Papuci-Władyka, J. Śliwa (IA JU, Kraków), R. Czerner (WUST, Wrocław), A. Ćwiek (IA AMU, Poznań), M. Wiewióra (IA NCU, Toruń), K. Domżalski

(IAE PAS, Warszawa), K.O. Kuraszkiewicz (DE FOS UW), M. Barwik, P. Bieliński, P. Dyczek, W. Godlewski, D. Ławecka, S. Rzepka, J. Żelazowski, M. Gawlikowski, J. Młynarczyk, A. Niwiński, T. Sarnowski, D. Szeląg, T. Waliszewski (IA UW, Warszawa)

\section{RÉDACTEUR THÉMATIQUE DU VOLUME \\ Barbara Lichocka}

\author{
AIDE RÉDACTION TECHNIQUE \\ Dorota Dobrzyńska, Mariusz Drzewiecki
}

REVUE DES TEXTES ANGLAIS

Jo Harper 
ÉTUDES et TRAVAUX XXX 
INSTYTUT KULTUR ŚRÓDZIEMNOMORSKICH I ORIENTALNYCH POLSKIEJ AKADEMII NAUK

\section{STUDIA i PRACE}

XXX

\section{Ro IKŚSiO \\ ESA PAN}

WARSZAWA

2017 
INSTITUT DES CULTURES MÉDITERRANÉENNES ET ORIENTALES DE L'ACADÉMIE POLONAISE DES SCIENCES

\section{ÉTUDES et TRAVAUX}

XXX

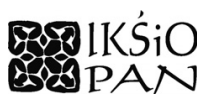

VARSOVIE

2017 
Publication scientifique financée dans le cadre du programme du Ministre de la Science et de l'Éducation Supérieure

« Programme National de Développement de l’Humanistique » pour les années 2016-2021 (projet no 3bH 150099 83)

\title{
HARODOWY PROGRAM ROZWOJU HUMANISTYKI
}

\author{
Copyright (C) \\ Instytut Kultur Śródziemnomorskich i Orientalnych PAN \\ et les Auteurs \\ Warszawa 2017
}

\author{
ISSN 2084-6762 \\ (avant $2011: 0079-3566$ ) \\ e-ISSN 2449-9579 \\ Version première en papier, imprimée en Pologne - 150 copies \\ Version électronique accessible sur \\ http://www.etudesettravaux.iksiopan.pl
}

Édition: Polskie Towarzystwo Historyczne et Wydawnictwo Neriton, Warszawa

Conception générale de couverture : J. Iwaszczuk

Photos de couverture : En haut, à gauche. Vieille Dongola 1991, S. Jakobielski

(debout à gauche), K. Pluskota (debout à droite), B. Żurawski (assis sur le camion)

et P. Wierzbicki (assis sur le camion) (de la collection de B. Żurawski)

En haut, à droite. Palmyre 1964, M. Marciniak au travail (phot. A. Dziewanowski)

Au centre. E. Laskowska-Kusztal au travail (de la collection de E. Laskowska-Kusztal)

En bas, à gauche. Tell Atrib 1962 ; de gauche : T. Biniewski, M. Marciniak, K. Kołodziejczyk,

K. Michałowski, A. Ostrasz, S. Jakobielski et S. Jasiewicz devant eux

(de la collection de IKŚSiO PAN).

En bas, à droite. Vieille Dongola 1976, S. Jakobielski nettoyant le mur (phot. M. Steinborn).

Au centre, à droite, K. Myśliwiec en train des travaux de documentation (de la collection de IKŚiO PAN) 


\section{Table des matières}

BARBARA LICHOCKA

Ergon agathon

Hartwig Altenmüller

$\mathrm{Zu}$ den Feindbildern auf den Zauberstäben des Mittleren Reiches und der Zweiten

Zwischenzeit

Nathalie Beaux

Des $m s w n s w$ de Thoutmosis III à Deir el-Bahari

Briant Bohleke, Nigel Strudwick

A Label for Opening of the Mouth Implements from the Burial of Senneferi (TT99)

and Remarks on the Ritual

Rosa Maria Bonacasa Carra, Nicola Bonacasa

Nuovi dati sugli edifici termali di Sabratha

EDWARD BROVARSKI

A Fragmentary Carrying Chair Scene in Salt Lake City, Utah

Julia Burdajewicz

Wall Painting Decoration from the North-West Church in Hippos-Sussita

of the Decapolis

Mariusz BURDAJEWICZ

From Pagan Temple to Church in Late Antiquity Palestine. A View from

Hippos-Sussita

MAREK ChlodNicki

Early Dynastic Bead Workshops at the Central Kom of Tell el-Farkha.

Patryk ChudziK, Mariusz Caban

Observations on the Architecture of the Tomb of Horhotep in Western Thebes

Krzysztof M. Cialowicz

New Discoveries at Tell el-Farkha and the Beginnings of the Egyptian State.

Amr EL-TiebI

Four Wooden New Kingdom Female Statuettes in the Egyptian Museum, Cairo 


\section{Naguib KanaWATI}

Ritual Marriage Alliances and Consolidation of Power in Middle Egypt during the Middle Kingdom

Adam Łajtar, Jolanta Mlynarczyk

A Faction Acclamation Incised on a Pithos Found Near the North-West Church at Hippos (Sussita)

Adam ŁaJTAR, Grzegorz OchaŁa

Two Private Prayers in Wall Inscriptions in the Faras Cathedral

Adam Łajtar, Anna Poludnikiewicz

Medicinal Vessels from Tell Atrib (Egypt)

JaCeK Michniewicz, Jolanta MlynarczyK

Petrographic Variability of the Fabrics of Wine Jars from Sha'ar-Ha Amakim as a Reflection of Differences in Their Provenance and Chronology

Iwona ModrzewsKa-PianetTI

Les importations d'amphores Dressel 20 en Gaule Cisalpine

Arthur SEgal

Samaria-Sebaste. Portrait of a polis in the Heart of Samaria 409

JOACHIM ŚLIWA

The Motif of a 'Blind Harper' in an Unexpected Place

MONIKA WIĘCH

Searching for the Kitchen in the Early Roman Phase of the 'Hellenistic' House at Nea Paphos (Cyprus)

Abréviations 
THE VOLUME IS PUBLISHED TO CELEBRATE

THE $60^{\text {TH }}$ ANNIVERSARY

OF THE ESTABLISHMENT OF

THE RESEARCH CENTRE FOR MEDITERRANEAN ARCHAEOLOGY POLISH ACADEMY OF SCIENCES

FOUNDED IN 1956

WHOSE MISSION IS CONTINUED BY

THE INSTITUTE OF MEDITERRANEAN AND ORIENTAL CULTURES

OF THE POLISH ACADEMY OF SCIENCES 